\title{
The structuring of narrative texts into figure and ground: attention, memory and language
}

\author{
Adriana Maria Tenuta* \\ Marcus Lepesqueur* \\ Maria Luiza Cunha Lima*
}

\begin{abstract}
Resumo
In narrative texts, some events compose the core story line and, due to their cognitive status of focus and salience, are grammatically and discursively marked as figure. Events that do not share this status are marked as narrative ground and provide information that support those central story elements (HOPPER, 1979; TENUTA, 2006). This process of figuration in narratives reflects the cognitive principle of human perception in terms of figure and ground, proposed by the Gestalt Psychology. (KOFFKA, 1975; WERTHEIMER, 1938). This article aims at reporting results of a study that investigated the process of figuration in oral narratives produced by 13 subjects. It was tested the hypothesis of a relation between the occurrence of figure or ground narrative units and tasks with distinct cognitive demands of attention and memory. A logistic regression model showed patterns of narrative structuring connected to specific task types. The results suggest a correlation between linguistic representation of information from memory (BADDELEY, 2007's memory model) and the amount of narrative ground structures. From Bruner (2002) and Chafe's (1990) perspectives, it is understood that narratives produced from memory content tend to have more ground units, with greater manipulation of cognitive models, not reflecting an objective representation of reality.
\end{abstract}

Keywords: Attention. Memory. Cognition. Narrative. Figure and ground.

\section{Introduction}

This paper presents results of a research that investigated contributions of linguistic narrative studies to the comprehension of some cognitive processes. In the research, we tested the hypothesis of a relation between the narrative structure and tasks with distinct cognitive demands of attention and memory. More specifically, this work analyzes the figuration process, i.e, the process of

* Universidade Federal de Minas Gerais (UFMG). 
distribution of linguistic figure and ground units in the narrative text.

The work was based on the assumption that there are some aspects of the narrative structure that relate to more general cognitive capacities, such as memory and attention. A rich body of research has brought to light strong evidence that attention and memory processes directly influence linguistic structure (TOMLIM, 1995; FORREST, 1997; GLEITMAN et al., 2007) in a conception that the grammars of languages reflect, in some ways, certain cognitive pressures. Among the functions and linguistic components that might be influenced by the attention and memory systems are those that apparently allow speakers' manipulation of attentional or informational focus. Examples of such components are: prosodic focus and intonation patterns of emphasis; syntactic structures, such as topicalization, verbal voices, clause constituent order; reference forms and the figuration process in narratives. Specifically, this figuration process is understood as the linguistic realization of a cognitive principle proposed by the Gestalt Psychology, as discussed in the following section.

\section{Figure and ground in narrative texts}

The Gestalt Psychology proposed that human perception (visual perception, mostly, but not only) is governed by the principle of selective attention. According to this principle, the perception of the figure, or salient element, occurs, invariably, over a more homogeneous and undifferentiated background. In this perceptual process, we always select certain aspects of the scene in relation to others, and the figure depends on the background for its characterization. (KOFFKA, 1975; WERTHEIMER, 1938).

When discussing the Gestalt principle of figure and ground, people frequently use the well known Rubin's Vase image. In this image, we see either a black vase or two white faces: we can not see the vase and the faces at the same time, with the same salience. The Gestalt postulate of selective attention helps us understand the structure and the limits of our cognitive apparatus of perception. The view of this image in alternating figures is not a choice, but a condition imposed to perception by this apparatus.

In the field of Cognitive Linguistics, language and cognition are integrated. The process of distribution of linguistic material into figure or ground narrative 
elements, here termed figuration, is understood as the Gestalt cognitive principle acting in language.

Figuration in language was initially perceived by Hopper (1979), who showed that the verbal system of time, aspect and mood - TAM system - has an essential role in marking the distinction between foreground and background in narratives. ${ }^{1}$ The TAM system constitutes a resource used by the speaker to organize his/her text and guide the listener in distinguishing the central narrative material, i.e. the line of sequential events (figure), from supplementary material (ground) (HOPPER, 1979; TENUTA, 2006).

Apart from TAM system markings, narrative figure and ground have other specific semantic-formal features. Part of those features was explained by Reinhart (1984) in terms of a parallel with the cognitive visual-spatial perception. This author proposed, based on Koffka (1975), that the process of figuration in narratives is governed by the same foundational principles that govern the spatial organization of visual perception, namely, 'continuity', 'punctuality' and 'completeness'.

First, Reinhart proposes, concerning visual perception, that 'continuity' refers to a tendency to see a figure if we can provide some continuity to the stimulus. To Reinhart (1982), in narratives, a temporal sequence of events is generally interpreted as figure due to the fact that it is perceived as a continuum. Second, the author states that the 'punctuality' principle informs us that a small or punctual element is more easily perceived as figure than a big one. Linguistically, 'punctuality' is achieved by verb semantics. Punctual verbs, the ones that represent events that are cognitively perceived as taking little time to occur (enter, arrive, let go, blink), are prototypically interpreted as figure, while durative verbs (stay, live, study) occur preferably as narrative ground. 'Completeness' or closure, the third principle discussed, makes the stimulus more easily perceived as figure. In language, this cognitive effect of completeness is achieved by the perfective aspect. Thus, the combination of those criteria results in a prototypical narrative figure characterized by a sequence of punctual verbs in the perfective past. $^{2}$

1 In Langacker's Cognitive Grammar $(1987,2008)$, figure and ground are correlated to the concepts of trajector, the first participant in a relationship, and landmark, the secondary participant. Under this theoretical model, the semantic value of any linguistic unit (profile) is defined in terms of the relationship between these two participants. Talmy (2000), corroborating the importance of the concepts of figure and ground, also deals with this distinction in terms of primary and secondary objects, related to prominence, salience or focus. Tenuta and Lepesqueur (2011) discuss several examples of the cognitive process of figuration in language, such as the oppositions subject/predicate, topic/comment and previous discourse/current discourse.

2 In Portuguese, the verb tense that corresponds to perfective past is pretérito perfeito. 


\section{Research procedures}

The study reported in this paper aimed at analysing distinct patterns of figuration in narratives produced in response to distinct tasks. There were 13 research participants ${ }^{3}$ between 9 and 12 years old, with normal performance in the D2 Test of concentrated attention.

Two comic strips ${ }^{4}$ and a short film, all without texts, ${ }^{5}$ were used as input for the production of the narratives. Beside those inputs, there was the request for each participant to produce an autobiographical narrative, related to a fact that he or she had experienced and considered 'important'.

The participants were interviewed individually. They were shown the film and two slide presentations containing the comic strips, picture by picture. In the slide presentations, the subjects had control over the computer keyboard, to move from one picture to the next. As for the film, it was presented all at once, and the subjects had no control over that presentation.

Each participant performed four tasks: 1. told a story while watching each picture in the comic strips; 2 . told a story after seeing all the pictures in the comic strips; 3 . developed the end of a story from the presentation of the short film; 4. produced an autobiographical narrative. Therefore, each participant produced, in the context of a single interview of about 20 minutes, four narratives: two of them (N1 and N2) based on two different comic strips, one of them (N3) based on a film, and another one (N4) in response to the request for a personal story. Each subject performed all tasks in a random order, defined at the time of data collection. The narratives collected were transcribed according to Castilho and Pretti (1986). ${ }^{6}$

Using these different tasks, we intended to observe the influence of various cognitive processes in the construction of narratives. In particular, we aimed

3 They were all students at Centro Pedagógico, UFMG, attending $4^{\text {th }}$ to $6^{\text {th }}$ year of primary school. 4 Papa Capim in Solta eles - Chico Bento n. 419, p. 26-32; Chico Bento in Goiabadas - Mônica n. 179, p. 28-32 and Red's dream by Pixar Animation Studios, 1987.

5 The title and name of the characters that originally appeared in the beginning of each story were withdrawn, so that this information could not have any influence on the understanding of the story by the subjects.

6 The notation is based on Castilho and Pretti (1986), adapted for the analysis. For example, we indicated pause duration longer than 1.5 seconds. We registered some speech characteristics of the participants, such as omissions of plural that were not conventional, or neologisms. On the other hand, we filled out phonological elements that are normally not provided by most of the speakers in Minas Gerais, Brazil, as with gerund: 'fazeno' was transcribed as 'fazendo'. 
at investigating the relationship between attention, memory, and the narrative structuring into figure and ground.

The specialized literature has provided evidence of a strong relationship between language and the processes of attention and memory. Psycholinguistic experiments, as the ones performed by Tomlin (1995), Forrest (1997) and Gleitman et al. (2007), have shown that attentional salience influences the syntactic structuring of sentences. Using images and attentional cues, these authors reported a relation between the perceptual salience of the stimulus and the syntactic position of its linguistic referent.

Studies conducted with clinical populations also suggest that changes in attention and memory processes have an impact on language production. Almor et al. (1999) found a strong correlation between working memory deficit and the use of pronominal forms for reference of discourse participants in the linguistic production of Alzheimer patients. Similarly, Cunha Lima and Tenuta (in press) show specific usage patterns of anaphoric elements in $\mathrm{ADHD}^{7}$ children's narratives. Menezes et al. (2007) and Montgomery (2003) suggest a relation between specific language impairment and the performance on tasks demanding visual and phonological memory.

Narrative figuration, investigated in this research, is among the linguistic functions and structures that might be influenced by the cognitive processes of attention and memory, since it constitutes one of the linguistic resources for the manipulation of informational and attentional focus.

The tasks proposed to the research participants for the production of their narratives were devised based on Baddeley's (2000) multiple components model of working memory. This model is known for offering a coherent explanation for several experiment results of memory studies. In this model, working memory has visual and phonological components (visuo-spatial sketchpad and phonological loop) coordinated by a central executive system that is responsible for: division of attention, selection of attentional focus, and organization of the relationship between working and long term memory (episodic buffer).

In the present research, task 1 differs from task 2 in terms of the kind of processing involved. Task 1 triggers a narrative production based on visuo-spatial attentional focus. On the other hand, task 2 triggers a final product primarily

7 Attention deficit hyperactivity disorder. 
based on the retrieval of information from short-term memory. ${ }^{8}$ Task 3 , on its turn, requires the creation of new content departing from previously presented information. Task 4, differently, requires the retrieval of autobiographical information from long-term memory. The data, then, was composed of narrative units of four types: N1, N2, N3, and N4, produced in response to task 1, task 2, task 3 , and task 4 , respectively.

The linguistic unit analyzed was the clause. ${ }^{9}$ Each clause was categorized as figure or ground. As previously stated, as figure, we find the central events of the story, and these events are usually expressed grammatically through independent or main clauses; as ground, which is the place for complementary information, such as description, judgment, evaluation, review, etc, we find independent, embedded, and subordinate clauses. This categorization took into account formal and semantic aspects, especially the verbal system of tense, aspect and mood. ${ }^{10}$

From a total of 1305 clause units, figure and ground clauses were counted in each narrative type, N1, N2, N3 and N4. Specific patterns of distribution of figure and ground in this narrative production were identified quantitatively, and the results are presented in the following section.

\section{Results}

The analysis of N1, N2, N3 and N4 indicated different patterns of narrative structuring in terms of the proportion of figure and ground elements. Table 1 shows the distribution of the 1305 clause units in each of these types of narrative.

8 We use short-term memory to refer, according to Baddeley (2011), to the performance on a task that involves the retention of small amounts of information after a small time period.

9 Clause, in this research, is a linguistic unit centralized by a verb. Discourse markers such as sabe?, acho que, tô entendendo (you know?, I think, I understand), were not considered clauses in the analyses. Structures such as pegou e disse and foi e fez (got and said, went on and did), or others, were computed as just one clause, since one of the constituent elements of these structures conveyed an aspectual meaning, rather than conveying a separate event. Furthermore, the cases of modal and aspectual periphrases were also counted as only one clause unit. Sequences produced as responses to interviewer's questions were not considered part of the narrative, neither were sequences of plain meta-narration.

10 We followed Reinhart (1982), considering subordinate and embedded clauses as ground units. Negative structures, unlike Reinhart, have been marked as figure, since they indicate development in the story and can be replaced by their assertive opposed elements (did not agree can be understood as disagreed). For a more specific discussion on classification criteria for figure and ground units see Tenuta (2006). 
Table 1 - Description of the analyzed corpus

\begin{tabular}{|c|c|c|c|c|c|c|}
\hline \multirow{2}{*}{$\begin{array}{l}\text { Clause } \\
\text { unit } \\
\text { category }\end{array}$} & \multirow{2}{*}{$\begin{array}{c}\text { Total } \\
\text { sample }\end{array}$} & \multicolumn{4}{|c|}{ Sample by task/narrative } & \multirow{2}{*}{$\begin{array}{l}\text { Participant } \\
\text { Subjects }\end{array}$} \\
\hline & & N1 & N2 & N3 & N4 & \\
\hline Figure & 740 & 378 & 164 & 61 & 137 & \\
\hline Ground & 565 & 175 & 189 & 22 & 179 & 13 \\
\hline Total & 1305 & 553 & 353 & 83 & 316 & \\
\hline
\end{tabular}

The data were analyzed using the R Statistical Software (R DEVELOPMENT CORE TEAM, 2012). Logistic regression was used to quantify the associations between the occurrence of narrative figure and ground (the categorical dependent variable) and the type of task involved in the production of narratives (the categorical independent variable). The subject who produced the narrative was also included as a predictor variable in the model. The contribution of each individual predictor was examined through Wald's test. Table 2 displays the logistic regression coefficient $(\beta)$ and the Wald's test result for each predictor. Table 3 displays the odds ratio $\left(\mathrm{e}^{\beta}\right)$ and its confidence intervals. 
Table 2 - Logistic regression analysis of 1305 clause units produced by 13 subjects in four different tasks

\begin{tabular}{|ccccc|}
\hline Predictor & $\begin{array}{c}\text { Regression } \\
\text { coefficients } \\
(\beta)\end{array}$ & Standard error & z value & P(Wald's Test) \\
\hline (Intercept) & -0.77979 & 0.19108 & -4.081 & $* * * 4.48 \mathrm{e}-05$ \\
N2 & 0.93301 & 0.14534 & 6.419 & $* * * 1.37 \mathrm{e}-10$ \\
N3 & -0.24850 & 0.27271 & -0.911 & 0.362 \\
N4 & 0.96638 & 0.15278 & 6.325 & $* * * 2.53 \mathrm{e}-10$ \\
Subject02 & -0.22832 & 0.30109 & -0.758 & 0.448 \\
Subject03 & -0.07004 & 0.24267 & -0.289 & 0.773 \\
Subject04 & 0.14543 & 0.22936 & 0.634 & 0.526 \\
Subject05 & 0.38693 & 0.24637 & 1.571 & 0.116 \\
Subject06 & -0.29238 & 0.48313 & -0.605 & 0.545 \\
Subject07 & 0.11630 & 0.33360 & 0.349 & 0.727 \\
Subject08 & -0.23094 & 0.30762 & -0.751 & 0.453 \\
Subject09 & -0.75072 & 0.33493 & -2.241 & $* 0.025$ \\
Subject10 & 0.33536 & 0.24366 & 1.376 & 0.169 \\
Subject11 & 0.10420 & 0.31379 & 0.332 & 0.740 \\
Subject12 & -0.34121 & 0.27494 & -1.241 & 0.215 \\
Subject13 & 0.16638 & 0.33171 & 0.502 & 0.616 \\
& &. d.f & & \\
Null deviance & 1785.6 & 1304 & & \\
Residual deviance & 1683.6 & 1289 & & \\
:AIC & 1715.6 & & & \\
\hline
\end{tabular}


Table 3 - Estimated odds ratio and confidence interval

\begin{tabular}{|cccc|}
\hline Predictor & Odds ratio & \multicolumn{2}{c|}{ Confidence interval } \\
\cline { 3 - 4 } & & Inf. $(2.5 \%)$ & Sup. (97.5\%) \\
\hline (Intercept) & 0.4585024 & 0.3139689 & 0.6648173 \\
N2 & 2.5421434 & 1.9143076 & 3.3850258 \\
N4 & 0.7799678 & 0.4490048 & 1.3136118 \\
Subject02 & 0.7958734 & 0.4378785 & 1.4294754 \\
Subject03 & 0.9323524 & 0.5790319 & 1.5006909 \\
Subject04 & 1.1565420 & 0.7381305 & 1.8155165 \\
Subject05 & 1.4724518 & 0.9095660 & 2.3916908 \\
Subject06 & 0.7464847 & 0.2815274 & 1.9053125 \\
Subject07 & 1.1233341 & 0.5796872 & 2.1525874 \\
Subject08 & 0.7937858 & 0.4316790 & 1.4459977 \\
Subject09 & 0.4720277 & 0.2400096 & 0.8971347 \\
Subject10 & 1.3984461 & 0.8683096 & 2.2590619 \\
Subject11 & 1.1098273 & 0.5968558 & 2.0482585 \\
Subject12 & 0.7109104 & 0.4126316 & 1.2146428 \\
Subject13 & 1.1810170 & 0.6126215 & 2.2577732 \\
\hline
\end{tabular}

The logistic model formula estimates the odds of occurrence of a selected response (figure or ground) as a function of predictor variables (the type of task and the subject who produced the narrative). None of the participants was a statistically significant predictor of the occurrence of narrative figure or ground. ${ }^{11}$ No individual subject manifested tendency for a specific pattern of figuration. The type of task, however, was a determinant factor $(p<0.001)$ for narrative structure. Concerning task types, the production of narrative ground is positively associated to N2 and N4 ( $<0.001)$, comparatively to N1 (intercept). More

11 Assuming a significance level of .01 . 
precisely, N2 and N4 increase, by a factor of 2.54 and $2.63\left(\mathrm{e}^{\beta}\right)$, respectively, the odds of occurrence of narrative ground, compared to N1.

Even though the model does not fit the entire data set exactly, since there is a highly significant difference between fitted values and observed values $\left(\chi^{2}=1683.6, \mathrm{df}=1289, \mathrm{p}<0,001\right)$, the logistic regression model has a better prediction performance comparatively to the null model, leading to a significant reduction in deviance $\left(\chi^{2}=102\right.$, df $\left.=15, \mathrm{p}<0,001\right)$. This means that while figuration depends on other non-modeled factors, the task type is crucial for the distribution of figure and ground in the narratives.

Task type influence on the figuration process can be better visualized through Graph 1. This mosaic plot graph displays the standardized residuals for a model in which task type and figuration are independent. The blocks have bases that are proportional to the figure or ground observed frequencies. The gray color indicates when the standard residue is lower than 2. This means an observed frequency that is much lower than expected for a model in which task type and figuration are independent. An intensification of this color, toward black, means an even lower residue (lower than 4). Conversely, the blocks with diagonal lines correspond to residues that are higher than 2, indicating an observed frequency that is much higher than expected. Thicker diagonal lines mean an even higher residue (hight

Mosaic Plot - Task by type of narrative unit

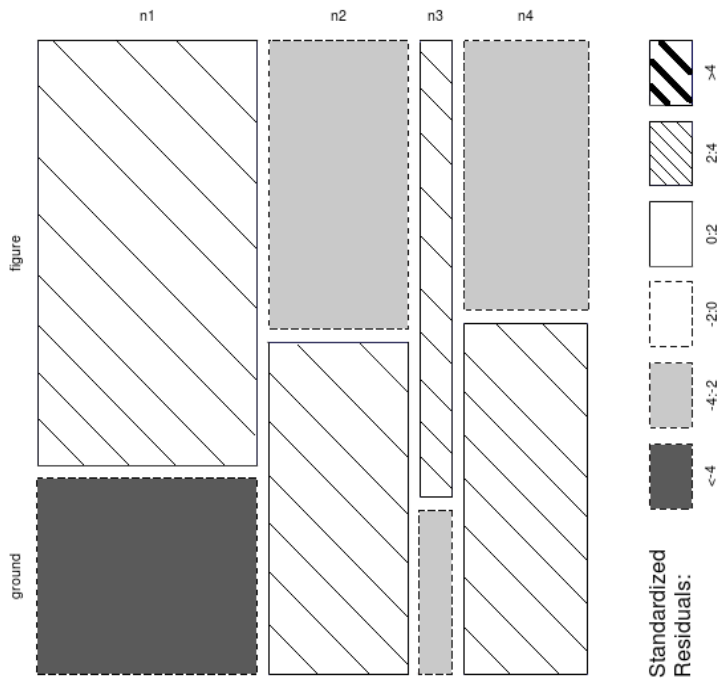


The graph shows similar characteristics of figuration for N1 and N3. This group of narratives displays ground occurrence that is lower than expected and figure occurrence that is higher than expected. Inversely, the other group, $\mathrm{N} 2$ and N4, displays figure occurrence that is lower than expected and ground occurrence that is higher than expected.

The difference in figure and ground proportions in the two groups of narratives was interpreted as a reflex of the different cognitive demands of the tasks involved in the production of those narratives. Task 2 and task 4 demand, respectively, the retrieval of information from short-term and long-term memory, without the aid of visual cues. In contrast, task 1 requires the immediate reproduction of content presented through visual input, demanding, therefore, a visual-spatial attentional focus. Task 3 , in its turn, involves the production of new content, based on some initial input.

\section{Discussion of Results and Conclusion}

Sinha assigns psychology the status of a 'bridge discipline' for biological, social and language aspects, and, according to the author, many of the theoretical concepts of Cognitive Linguistics were adopted from Cognitive Psychology. Sinha, in this context, acknowledges insights from Cognitive Linguistics related to "what have traditionally been known as the 'higher mental processes': memory, reasoning, and language" (SINHA, p. 1268).

There are, therefore, notions that are common to both linguistics and psychology, making studies of linguistic phenomena decisive for the investigation of specific aspects of cognition. Schema, frames, and mental models, for example, from Cognitive Psychology, are used in Cognitive Linguistics. For Bruner (1990), in Cognitive Psychology, mental models and schemas are cognitive structures that provide meaning and organization to experience. In Cognitive Linguistics, several linguistic phenomena are explained, more or less explicitly, 
through the same notions of schemas, frames (FILLMORE, 1982; CIENKI, 2007), or cognitive models (LAKOFF, 1987). These cognitive structures, then, organize language but are part of our conceptual system, i.e. they structure the way we understand the world and make sense of our experiences.

Thus, since the notions of schemas, frames, and mental models base both the construction of linguistic meaning and the structuring of certain psychological mechanisms related to the understanding of the experience by the subject, we believe that linguistic studies can serve purposes of psychological investigations, such as the one conducted through this research. Our linguistic figure and ground quantitative analysis led us to the postulation of a relationship between narrative structure, in linguistics, and attentional focus and memory, in psychology.

The higher proportion of narrative ground in relation to figure in N2 and N4 suggests a relationship between the amount of ground structures and the cognitive demand for retrieval of information from memory. This pattern of narrative structuring of an increased proportion of narrative ground can be understood in both Bruner (2002) and Chafe's (1990) perspective. Our memory does not serve truth (BRUNER, 2002), and our mind does not represent an external reality in a trustworthy manner, but creates it according to its own mixture of cultural and individual expectations (CHAFE, 1990). To those authors, our narratives are basically structured by schemas, frames and cognitive models. Thus, aspects of the world and of ourselves are reformulated and enriched in this storytelling process. A narrative can be seen not only as a discourse type or genre, but also as a cognitive ability to organize experience, through which the human being internally reinforces, destroys and reconstructs models of the world, making sense of experience (BRUNER, 2002).

A proportionally higher amount of ground in N2 and N4 can be interpreted, then, as the result of a reconstruction and enrichment process from memory content. That is, the content of the narratives is not restricted to the sequence of events in the story line (narrative figure). N2 and N4 elude objective representation of reality and moves toward the manipulation of world models and schemas. These narratives that have proportionally more ground elements than figure elements present more comments, explanations, evaluations, etc. On the other hand, N1 and N3 do not deal essentially with memory content, and 
may, therefore, be more objective in terms of the events represented in the story.

The research reported here reinforces the importance of interdisciplinary work to reach broader understanding of certain phenomena. In addition, this research supports a central tenet of Cognitive Linguistics, which is the intrinsic relationship between language and cognition, indicating, specifically, that linguistic studies of the narrative may shed light on psychological aspects of individuals.

There was also a significant methodological contribution of this study regarding linguistic narrative research in general. There are tasks that demand retrieval of information from short-term memory with our without visual cues; other tasks demand retrieval of information from long-term memory; still others demand content that is created or imagined. The study revealed that tasks with specific cognitive demands result in specific patterns of narrative structuring.

Naturally, there are other lines of investigation that can be assumed departing from this research. These investigations can, for example, involve clinical populations related to attention and memory disorders, such as ADHD and Alzheimer. Also, there can be investigations of more qualitative aspects of the figuration performed by subjects. This would complement the study conducted here and provide conditions to make further generalizations concerning the relationship among narrative structure, attentional focus, and memory. 


\title{
A estruturação de textos narrativos em figura e fundo: atenção, memória e linguagem
}

\begin{abstract}
Resumo
Nos textos narrativos, alguns eventos compõem a linha principal da história e, devido ao seu estado cognitivo de foco e saliência, são gramatical e discursivamente marcados como figura. Eventos que não compartilham esse status são marcados como fundo narrativo e fornecem informações que sustentam os elementos centrais da história (HOPPER, 1979; TENUTA, 2006). Esse processo de figuração em narrativas reflete o princípio cognitivo da percepção humana em termos de figura e fundo proposto pela psicologia da Gestalt (KOFFKA, 1975; WERTHEIMER, 1938). Este artigo tem como objetivo relatar os resultados de um estudo que investigou o processo de figuração em narrativas orais. Analisamos unidades oracionais de textos narrativos, produzidos por 13 indivíduos, a partir de tarefas com demandas cognitivas distintas de atenção e memória. Foi testada a hipótese de uma relação entre a ocorrência de unidades de figura ou fundo narrativos e tarefas específicas, utilizando um modelo de regressão logística. Foram encontrados padrões específicos de estruturação das narrativas a depender do tipo de tarefa. O modelo estatístico utilizado sugeriu uma correlação positiva entre a representação linguística de informação proveniente da memória (nos termos de Baddeley, 2007) e a quantidade de estruturas de fundo narrativo. Compreende-se, com base nas perspectivas de Bruner (2002) e Chafe (1990), que narrativas produzidas principalmente a partir de conteúdos da memória tendem a apresentar mais unidades de fundo, fugindo de uma representação objetiva da realidade, com uma maior manipulação de modelos cognitivos.
\end{abstract}

Palavras-chave: Atenção. Memória. Cognição. Narrativa. Figura e fundo.

\section{References}

ALMOR, Amit; KEMPLER, Daniel; MACDONALD, Maryellen C.; ANDERSEN, Elaine S.; TYLER, Lorraine K. Why do Alzheimer patients have difficulty with pronouns? Working memory, semantics, and reference in comprehension and production in Alzheimer's disease. Brain and language, v. 67, p. 202-227, 1999.

BADDELEY, Alan D. The episodic buffer: A new component of working memory? Trends in Cognitive sciences, v. 4, n. 11, p. 417-423, 2000. 
BADDELEY, Alan D. Working memory, thought and action. Oxford: Oxford University Press, 2007.

BRUNER, Jerome. Acts of meaning. Cambridge: Harvard University Press, 1990. BRUNER, Jerome. Making stories. Cambridge: Harvard University Press, 2002. CASTILHO, Ataliba Teixeira de. PRETTI, Dino (Ed.). A linguagem falada culta. São Paulo: T. A. Queiroz, 1986.

CHAFE, Wallace. Some things that narrative tells us about the mind. In: BRITTON, Bruce K.; PELLEGRINI, Anthony D. Narrative thoughts and narrative language. New Jersey: Lawrence Erlbaum, 1990.

CIENKI, Alan. Frames, idealized cognitive models, and domains. In: GEERAERTS, Dirk; CUYCKENS, Hubert. The Oxford handbook of cognitive linguistics. Oxford: Oxford University Press, 2007. p. 170-187.

CUNHA LIMA, Maria Luiza; TENUTA, Adriana M. Aspectos atencionais da linguagem: a escolha da forma referencial em narrativas de crianças portadoras de TDAH In: MOTA, M. Perspectivas da psicolinguística. Petrópolis: Vozes. In press.

FILLMORE, Charles J. Frame semantics. In: Linguistic Society of Korea (Ed.). Linguistics in the morning calm. Seoul: Hanshin, 1982. p. 111-37.

FORREST, Linda B. Discourse goals and attentional processes in sentence production: the dynamic construal of events. In: GOLDBERG, Adele E. (Ed.). Conceptual structure, discourse and language. Stanford: CSLI Publications, 1997. p. 149-162.

GLEITMAN, Lila R.; JANUARY, David; NAPPA, Rebecca; TRUESWELL, John C. On the give and take between event apprehension and utterance formulation. Journal of memory and language, v. 57, p. 544-69, 2007.

HOPPER, Paul J. Aspect and foregrounding in discourse. In: GIVON, Talmy (Ed.). Syntax and semantics. New York: Academic Press, 1979. p. 213-241.

KOFFKA, Kurt. Princípios da psicologia da gestalt. Tradução de Álvaro Cabral. São Paulo: Cultrix, 1975. Original publicado em 1935.

LAKOFF, George. Women, fire, and dangerous things: What categories reveal about the mind. Chicago: University of Chicago Press, 1987.

LANGACKER, Ronald W. Foundations of cognitive grammar: Theoretical prerequisites. Stanford, CA: Stanford University Press, 1987. v. 1. 
LANGACKER, Ronald W. Cognitive grammar: a basic introduction. New York: Oxford University Press, 2008.

MENEZES, Camila Gioconda de Lima e; TAKIUCHI, Noemi; BEFI-LOPES, Debora Maria. Visual short-term memory in children with specific language impairment. Pró-Fono Revista de atualização científica, Barueri, v. 19, n. 4, dez. 2007. Disponível em: <http://www.scielo.br/scielo.php?script=sci_arttext\& pid $=$ S0104-56872007000400007\&lng=en\&nrm=iso $>$. Acesso em: 14 out. 2013.

MONTGOMERY James W. Working memory and comprehension in children with specific language impairment: what we know so far. Journal of communication disorders, v. 36, n. 3, p. 221-31, 2003.

REINHART, Tanya. Principles of gestalt perception in the temporal organization of narrative text. Linguistics, v. 22, n. 6, p. 779-809, 1984.

R DEVELOPMENT CORE TEAM, The R project for statistical computing, 2012. Disponível em: <http://www.r-project.org/>.

SINHA, Chris. Cognitive linguistics, psychology and cognitive science. In: GEERAERTS, Dirk; CUYCKENS, Hubert (Ed.). The Oxford handbook of cognitive linguistics. Oxford: Oxford University Press, 2007. p. 1.266-1.294.

TALMY, Leonard. Toward a cognitive semantics: concept structuring systems. Cambridge, MA: The MIT Press, 2000. v. 1.

TENUTA, Adriana Maria. Estrutura narrativa e espaços mentais. Belo Horizonte: Faculdade de Letras da UFMG, 2006.

TENUTA, Adriana Maria; LEPESQUEUR, Marcus. Aspectos da afiliação epistemológica da Linguística Cognitiva à Psicologia da Gestalt: percepção e linguagem. Ciências \& cognição. v. 16, n. 2, p. 65-81, 2011.

TOMLIM, Russel S. Focal attention, voice, and word order: an experimental, cross-linguistic study. In: DOWNING, Pamela; NOONAN, Michael (Ed.). Word order in discourse. Amsterdam: John Benjamins, 1995. p. 517-554.

WERTHEIMER, Max. Gestalt theory. In: ELLIS, Willis D. (Org.). A source book of gestalt psychology. London: Routledge \& Kegan Paul, 1938. 